Ann. Biol. anim. Bioch. Biophys., 1979, 19 (4 B), 1363-1367.

\title{
LH/HCG receptors of the ovary during early postnatal development
}

\author{
par U. MÜLLER, W. ENGEL *, J. W. SIEBERS ** \\ Instifut für Humangenetik und Anthropologie der Universität, D-7800 Freiburg, Albertstr. 11, FRG \\ * Instituf fur Humangenetik der Universitat, D-3400 Gottingen, Nikolausberger Weg 5a, FRG \\ ** Universitats-Frauenklinik, D-7800 Freiburg, Hugstetterstr. 55, FRG.
}

Summary. Ovaries of neonatal rats are not endowed with specific LH/HCG receptors up to 6-8 days of age. However, when ovarian membranes of newborn or 5-day old rats were treated with neuraminidase, specific binding for ${ }^{125}$-HCG was detectable. The number of HCG binding sites in the neuraminidase-treated neonatal ovaries was nearly identical to the ovarian HCG binding capacity of 10-day old rats. In the ovaries of 10-26-day old rats the number of HCG receptors was elevated by neuraminidase treatment by about 15-25 p. 100 as compared to untreated control rats.

From these results we assumed the presence of HCG receptor-precursors or cryptic structures of the receptors which became active in neonatal rats between 6 and 8 days of age.

Fœtal and neonatal testes specifically bind HCG (Frowein and Engel, 1974). From the $\mathrm{H}-\mathrm{Y}$ antigen conversion of newborn ovarian cells into testicular tissue in Mosconatype reaggregation experiments (Müller ef al., 1978), the testicular HCG receptor may be considered as a constitutive protein in rats and humans appearing with the first formation of the Leydig cells in the primordial testis (Frowein, Engel and Weise, 1973). Contrary to the situation in the testis, in the rat ovary the HCG-receptorprotein is not constitutively expressed during development. Ovarian tissues of prenatal, newborn and 5-day old rats do not specifically bind HCG (Presl et al., 1972 ; Siebers et al., 1977). HCG receptors in the rat ovary are first detected during postnatal development between days 6 and 8, which coincides with the onset of LH or HCG sensitivity of the postnatal ovary (Lamprecht et al., 1973 ; Presl et al., 1969 ; Lamprecht ef al., 1976).

Depending on the physiological stage of the ovary during the menstrual cycle, HCG binding is found in interstitial tissue, corpora lutea and the theca and granulosa cells of large, antral follicles (Midgley Jr., 1973). From the observation that only the interstitial tissue of the ovary is steroidogenic in 10-day old female rats, one might assume that the interstitial cells are the first cells in the ovary to become endowed with LH/HCG-receptors. 
Since Lee and Ryan (1973) have shown that HCG binding in ovarian membranes is enhanced by neuraminidase treatment the existence of receptor precursors is to be discussed. The present study was performed to find out whether HCG receptor precursors are present in the neonatal rat ovary, i. e. before the HCG receptor is detectable, which become functional under neuraminidase action.

\section{Materials and methods.}

Rats of the strain SIV 50 were used. Neuraminidase (E. C. 3.2.1.18) from Clostridium perfringens was obtained from Boehringer (Mannheim/FRG). The rats were killed by decapitation, and the ovaries removed immediately and trimmed of fat and connective tissue under a stereomicroscope. A $1: 10(\mathrm{w} / \mathrm{v})$ tissue homogenate was prepared in cold Tris- $\mathrm{HCl}$ buffer $\left(0.04 \mathrm{~mol} / \mathrm{l}, \mathrm{pH} 7.3\right.$, containing $\left.\mathrm{MgSO}_{4}(0.005 \mathrm{~mol} / \mathrm{l})\right)$, using 10 strokes of a glass-teflon homogenizer. After centrifugation of the homogenate at $100 \times \mathrm{g}$ for $15 \mathrm{~min}$ the supernatant was centrifuged again at $12000 \times \mathrm{g}$ and the

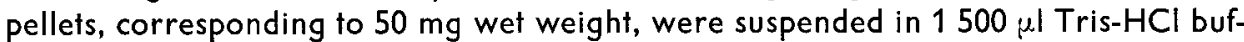
fer containing $50 \mu \mathrm{g}$ neuraminidase; these were incubated for $30 \mathrm{~min}$ at $37^{\circ} \mathrm{C}$. Reaction was stopped by the addition of $1 \mathrm{ml}$ ice-old Tris- $\mathrm{HCl}$ buffer and the membranes were washed twice at a $1 / 10$ ratio in Tris- $\mathrm{HCl}$ buffer. From this homogenate the HCG receptor was determined as described earlier (Siebers et al., 1977). In a further experiment the ovaries of 26-day old rats were preincubated with ${ }^{125}$ l-HCG for 30 min at $37^{\circ} \mathrm{C}$. One part was treated with neuraminidase afterwards as described above, and the other served as a control. The amount of ${ }^{125}$-HCG in the pellet and supernatant of both parts was determined after 2 washings.

\section{Results.}

The ovaries of newborn and 5-day-old rats did not specifically bind 125-HCG (table 1). However, neuraminidase treatment of the ovarian membranes of early postnatal rats resulted in a specific binding for ${ }^{125}$-HCG. Highly purified follicle stimulating hormone (FSH) (Serono, Freiburg, FRG) and ovine prolactin (oPRL) (Ferring, Kiel, FRG) (data not shown) did not compete with ${ }^{125}$-HCG for binding. Furthermore, failure to demonstrate HCG binding in liver and spleen homogenates, even after neuraminidase treatment (data not shown), indicated that the HCG binding in the ovaries of neonatal rats after neuraminidase action was due to the appearance of specific receptors.

The dissociation constants $\left(K_{D}\right)$ of the receptor-hormone complexes were nearly identical in 10-day old confrol rats and in the neuraminidase-treated ovarian membranes of newborn, 5-day and 10-day old rats (table 1). The number of ovarian HCG-binding sites in newborn and 5-day old rats after neuraminidase treatment amounted to 0.98 and $1.00 \times 10^{-15}$ moles $/ \mathrm{mg}$ wet weight, respectively (fig. 1, table 1 ). These data corresponded well to the number of specific HCG-receptors found in the ovaries of 10-day old control rats. Corresponding to the results of Lee and Ryan (1973), the neuraminidase treatment of the ovarian homogenates of 10 - to 26-day old rats enhanced HCG-binding by about 20 p. 100 as compared to control ovaries. Ovarian homo- 
genates of 26-day old rats preincubated with ${ }^{125}$ |-HCG did not release the hormone with the neuraminidase treatment used in our experimental conditions. The amount of 125-HCG in the pellet and supernatant was identical in control and neuraminidasetreated ovaries (data not shown).

TABLE 1

Binding of ${ }^{125}$ /-HCG by neuraminidase-treafed and untreated ovarian homogenates from rats at various stages of development. The mean values $\pm \mathrm{SE}$ of at least 5 experiments are included

\begin{tabular}{|c|c|c|c|c|}
\hline \multirow[b]{2}{*}{ Age (days) } & \multicolumn{2}{|c|}{ Neuraminidase-treated ovaries } & \multicolumn{2}{|l|}{ Controls } \\
\hline & $\begin{array}{l}\text { Number of binding sites } \\
\left(\mathrm{mol} / \mathrm{mg} \text { wet wt } \times 10^{-15}\right)\end{array}$ & $\begin{array}{c}\text { Dissociation } \\
\text { constants } \\
\left(\mathrm{mol} / \mathrm{I} \times 10^{-10}\right)\end{array}$ & $\begin{array}{l}\text { Number of binding sites } \\
\left(\mathrm{mol} / \mathrm{mg} \text { wet w } \times 10^{-15}\right)\end{array}$ & $\begin{array}{c}\text { Dissociation } \\
\text { constants } \\
\left(\mathrm{mol} / \mathrm{I} \times 10^{-10}\right)\end{array}$ \\
\hline Newborn.... & $0.98 \pm 0.07$ & 1.61 & - & - \\
\hline$\ldots \ldots \ldots$ & $1.00 \pm 0.12$ & 1.85 & - & - \\
\hline $10 d$ & $1.73 \pm 0.13$ & 1.88 & $1.34 \pm 0.18$ & 1.80 \\
\hline $17 \mathrm{~d} \ldots \ldots \ldots$ & $2.01 \pm 0.30$ & 1.92 & $1.61 \pm 0.25$ & 1.92 \\
\hline $26 \mathrm{~d} \ldots \ldots \ldots$ & $3.59 \pm 0.40$ & 1.71 & $2.90 \pm 0.26$ & 1.40 \\
\hline
\end{tabular}

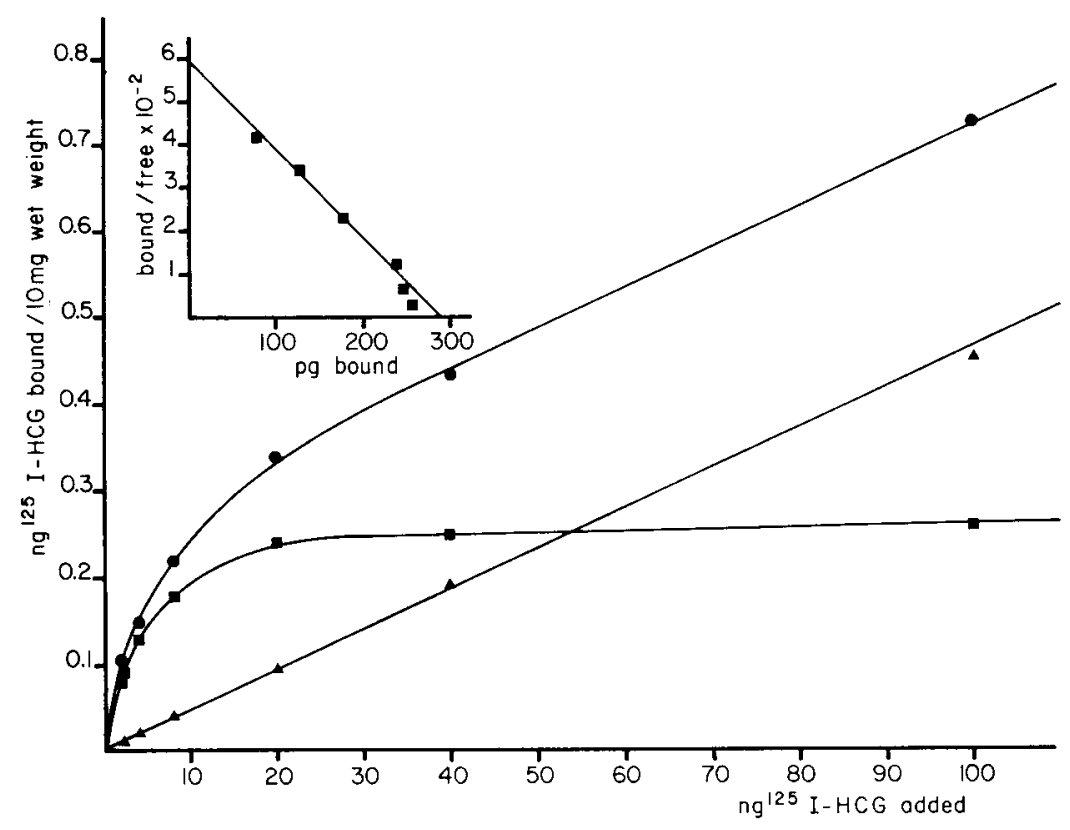

FIG. 1. - Binding of ${ }^{125}$ /-HCG by neuraminidase-treated ovarian homogenafes from newborn rats and Scatchard plot of the specific data. •-— binding in the presence of ${ }^{125}$ l-HCG alone; $-\mathbf{\Delta}$ binding in the presence of a 1000 -fold excess of unlabelled HCG ; - - specific binding. 


\section{Discussion.}

In the ovaries of newborn and 5-day old rats specific binding for LH or HCG has not been demonstrated. The insensitivity of the ovaries at that developmental stage seems to be due to the lack of specific receptors (Presl ef al., 1972 ; Siebers et al., 1977). The ovaries first become sensitive to endogenous or exogenous LH or HCG with respect to CAMP production and steroid biosynthesis, with the appearance of the specific $\mathrm{LH} / \mathrm{HCG}$ receptor between 6 and 8 days of age (Lamprecht ef al., 1973,1976). The appearance of LH/HCG-receptors in the ovarian membranes of newborn and 5-day old rats and the enhanced HCG-binding of immature rat ovaries after in vitro incubation with neuraminidase lead to the conclusion that neuraminidase plays an important role in LH/HCG-receptor activation.

Neuraminidase acts on various cell surface structures, e. g. lymphocytes treated with neuraminidase are more susceptible to lysis with antisera directed against HLA antigens than are the corresponding cells incubated in buffer (Grothaus ef al., 1971). The specifity of the HLA antigen, however, is not altered by neuraminidase (Parham et al., 1974). The specificity of the HCG receptors detected in the ovarian membranes of newborn and 5-day old rats after treatment with neuraminidase was not altered either :

1. the $K_{D}$ of the receptor-hormone complex of ovaries treated with neuraminidase was identical to that of untreated control ovaries ;

2. proteohormones like hFSH and oPRL did not compete with 125 |-HCG for binding in neuraminidase-treated ovaries;

3. non-target organs like the liver and spleen, which are not endowed with specific HCG receptors, do not bind HCG either after treatment with neuraminidase.

Since neuraminidase does not release in vitro-bound ${ }^{125}$-HCG from its receptor, the appearance of HCG receptors in neonatal rat ovaries and the enhanced HCG binding in ovaries of immature rats by neuraminidase treatment cannot be explained by a release of endogenously bound LH and therefore by an unmasking effect of previously occupied receptors.

Our results and those described by Lee and Ryan (1973) make it likely that either precursors of the $\mathrm{LH} / \mathrm{HCG}$ receptor or cryptic structures of the receptor, present in the ovarian cell membrane, are activated by neuraminidase action. Similar findings were described for the insulin receptor after phospholipase treatment of cell membranes (Cuatrecasas, 1971). However, the mechanism of receptor activation is unknown. From the observation that bovine brain gangliosides (Lee ef al., 1976) as well as gangliosides extracted from testes (Pacuszka ef al., 1978) inhibif 125/-HCG binding to testicular membranes, it can be speculated that the activation of HCG-receptor precursors is caused by a neuraminidase-catalyzed hydrolysis of gangliosides in the cell membrane.

4th Workshop on « Development and maturation of the reproductive organs and functions $\gg$ Luynes, France, octobre 1978. 
Acknowledgments. - This work was supported by the Deutsche Forschungsgemeinschaft. The authors thank Prof. U. Wolf for reading the manuscript. The technical help of Margarete Linding and Rita Rudolph is highly appreciated.

Résumé. Les ovaires de rattes ne possèdent pas de récepteurs spécifiques à $\mathrm{LH} / \mathrm{HCG}$ avant le $6 \mathrm{e}_{-} 8 \mathrm{e}$ jour après la naissance. Cependant, si les membranes cytoplasmiques d'ovaires de rattes nouveau-nées ou de rattes de 5 jours sont soumises à l'action de la neuraminidase, une fixation spécifique de HCG est détectable. Le nombre de sites de fixations après le traitement est presque identique à celui trouvé pour des ovaires de rattes de 10 jours. Dans les ovaires des rattes de 10 à 26 jours, le nombre de récepteurs à HCG est accru de 15 à 25 p. 100 par action de la neuraminidase par rapport aux ovaires témoins non traités.

De ces résultats il paraît exister dans l'ovaire des précurseurs des récepteurs à HCG ou des structures masquant ces récepteurs avant l'âge de 6-8 jours.

\section{References}

CUATRECASAS P., 1971. Unmasking of insulin receptors in fat cells and fat cell membranes. J. Biol. Chem., 246, 6532-6542.

FROWEIN J., ENGEL W., 1974. Constitutivity of the HCG-receptor protein in the testis of rat and man. Nature, 249, 377-379.

FROWEIN J., ENGEL W., WEISE H. Ch., 1973. HCG receptor present in the gonadotrophin insensitive Leydig cell of the immature rat. Nature, 246, 148-150.

GROTHAUS E. A., FLYE M. W., YUNIS E., AMOS D. B., 1971. Human lymphocyte antigen reactivity modified by neuraminidase. Science, 173, 542-544.

LAMPRECHT S. A., ZOR U., TSAFRIRI A., LINDNER H. R., 1973. Action of prostaglandin $E_{2}$ and of luteinizing hormone on ovarian adenylate cyclase, protein kinase and ornithine decarboxylase activity during postnatal development and maturity in the rat. J. Endocr., 57, 217-233.

LAMPRECHT S. A., KOHEN F., AUSHER J., ZOR U., LINDNER H. R., 1976. Hormonal stimulation of oestradiol-17 $\beta$ release from the rat ovary during early postnatal development. J. Endocr., 68, 343-344.

LEE C. Y., RYAN R. J., 1973. Luteinizing hormone receptors in luteinized rat ovaries, 419-430. In O'MALLEY B. W., MEANS A. R., Recepfors for reproductive hormones, Plenum Press, New York, London.

LEE G., ALOJ S. M., BRADY R. O., KOHN L. D., 1976. The structure and function of glycoprotein hormone receptors : Ganglioside interactions with human chorionic gonadotropin. Biochem. Biophys. Res. Com., 73, 370-377.

MIDGLEY A. R. Jr., 1973. Autoradiographic analysis of gonadotropin binding to rat ovarian tissue sections. Adv. exper. Medic. Biol., 36, 365-378.

MÜLLER U., ZENZES M. T., BAUKNECHT Th., WOLF U., SIEBERS J. W., ENGEL W., 1978. Appearance of HCG-receptor after conversion of newborn ovarian cells into testicular structures by $\mathrm{H}-\mathrm{Y}$ antigen in vitro. Hum. Gen., 45, 203-207.

PACUSZKA T., OSBORNE J. C. Jr., BRADY R. O., FISHMAN P. H., 1978. Interaction of human chorionic gonadotropin with membrane components of rat testes. Proc. nat. Acad. Sci. 75, $764-$ 768.

PARHAM P., HUMPHREYS R. E., TURNER M. J., STROMINGER J. L., 1974. Heterogeneity of HL-A antigen preparations is due to variable sialic acid content. Proc. nat. Acad. Sci., 71, 3998-4001.

PRESL J., HERZMANN J., HORSKY J., 1969. Oestrogen concentrations in blood of developing rats. J. Endocr., 45, 611-612.

PRESL J., POSPISIL J., FIGAROVA V., WAGNER V., 1972. Developmental changes in uptake of radioactivity by the ovaries, pituitary and uterus after ${ }^{125}$-labelled human chorionic gonadotrophin administration in rats. J. Endocr., 52, 585-586.

SIEBERS J. W., PETERS F., ZENZES M. T., SCHMIDTKE J., ENGEL W., 1977. Binding of human chorionic gonadotrophin to rat ovary during development. J. Endocr., 73, 491-496. 